7. Slosanska, G.I. (2014). Features of training of social workers for work in rural areas. Experience of the Austrian and Ukrainian.

8. Barker, J.A. (1993). Paradigms: Business of Discovering the Future. HarperCollins.

9. Bondar, T.V. (2011). The level of distribution and trends of tobacco use, alcoholic beverages and nar- cotic substances among ukrainian pupils. Kyiv: Obnova.10. Agarkov, O. A. Arabadzhiev, D. Y. (2015). Technologies of social work: manual with a stamp of the Ministry of Education and Science of Ukraine. Zaporozhye: Motor-Sich JSC Complex.

SAIKO Natalia,

Assistant Professor of Special Education and Social Work Department, Poltava V.G. Korolenko National Pedagogical University

\title{
MODELS OF ORGANIZATION OF SOCIAL WORK IN TERRITORIAL COMMUNITIES
}

Abstract. Introduction. The issue of the creation of territorial communities that would independently solve the issues of social improvement of a certain territory is very actual in the context of the decentralization of power in Ukraine. Solving these tasks involves improving the org?ization and implementation of the tasks of social work, first of all, in rural areas, as social life of the rural sector is always distinguished by the complexity of social and economic conditions

The purpose is outline of the basic models of organization of social work in the territorial community.

The methods of comparison, generalization, observation, systemic analysis, theoretical cognition, the method of analogy.

Results. We have identified an integrative and deficient model as main models of organization of social work in the territorial community in rural areas. An integrative model, or socialization, involves creating conditions for a normal social functioning of the indiv?dual. This includes improvement of village infrastructure, business development, cultural, leisure, cognitive and sports centers, creative associations, research centers and others, as well as the formation of the need for the younger generation to discover the world, develop personality, and take care of health. We consider establishment of international and regional projects and programs of social improvement of the territory, use of capacities of such international organizations as UN (UNICEF), NATO, etc. as the powerful mechanism of village development. The deficit model of social work, aimed at realization the tasks of social work in the territorial community, involves working with socially vulnerable population groups. The essence of this model lies in controlling the part of the population that show a tendency to deviant behavior, or for various objective and subjective reasons, is not able to independently solve the problems of socialization. It will be more effective in the case of the organization of various structures (rehab?litation, correction centers, centers of social assistance, advisory centers, etc.) in rural areas, which will help to restore, improve the social functioning of the person at a high professional level.

Originality. The necessity of organizing social work in the territorial community has been substantiated in two models based on the analysis of the problems of socia?ization of the individual in rural areas. They are integration and scarcity methods.

Conclusion. To sum up, in order to solve the problems of the modern village, the basic models of organization of social work in the territorial communities should be integration and deficient model with the dominant development of the first one.

Keywords: socialization; social activity; integration; model; integration model; scarcity model.

Отримано редакиією 17.01.2019 Прийнято до публікаиї 21.01.2019

DOI 10.31651/2524-2660-2019-2-156-162

ORCID 0000-0003-4858-0983

\section{МИХАЙАЕНКО Оксана Володимирівна,}

доцент кафедри соціальної роботи,

Національний університет "Чернігівський колегіум" імені Т.Г. Шевченка

e-mail: omikhailienko87@gmail.com

УДК 373.5.043.2-056.2/.3

\section{ОСНОВНІ НАПРЯМИ ПСИХОАОГО-ПЕДАГОГІЧНОГО СУПРОВОДУ ПІДАІТКІВ З ОСОБАИВИМ ОСВІТНІМИ ПОТРЕБАМИ В УМОВАХ ІНКАЮЗИВНОЇ ОСВІТИ}

У статі визначені перспективні напрями психолого-педагогічного супроводу підлітків з особливими освітніми потребами в умовах закладів загальної середньої освіти в умовах інклюзивної освіти, розглянуто значення основних методів у розв'язанні завдань розвитку $i$ соиіалізаиї кожної дитини у відповідності з ї̈ психофізіологічними особливостями.

Ключові слова: діти і підлітки з особливими освітніми потребами, психологопедагогічний супровід дітей $з$ особливими освітніми потребами, інклюзивна освіта, інклюзивне навчання, команда психологопедагогічного супроводу.

Постановка проблеми. В Україні, як у всьому цивілізовану світі, дитинство визнається важливим етапом у житті мюдини та детермінується принципом пріоритетності підготовки дітей до повноцінного життя у суспільстві, розвитку у них соціально цінних якостей.

У нашій державі, як і в інших країнах світу, спостерігається негативна тенденція збільшення кількості дітей 3 інвалідністю. А відтак, наразі існує гостра проблема залучення дітей і підмітків, що мають особливості розвитку, до соціуму, проблема їхньої активної адаптації, соціалізації і розвитку в межах суспільства та на благо суспільства.

Соціальна адаптація - це не подомання вад дітей, які мають порушення розвитку, з подальшої інтеграцією їх до вже звичного дия загалу ритму життя. Це 


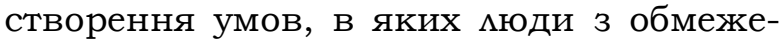
ними можливостями мали змогу вести повноцінне, гідне Взаємовідносини мюдей з інвалідністю та здорових мюдей - потужний фактор адаптаційного процесу.

Відповідно до Конвенції про права дитини та Конституції України кожна дитина має право на отримання освіти. Комітетом ООН з економічних, соціальних та культурних прав виділяють чотири основні характеристики права на освіту: наявність, доступність, сприйнятмивість та адаптованість. Доступність означає, що держава зобов'язана забезпечити рівний доступ до освіти дмя всіх незалежно від віку, статі, стану здоров'я тощо. Сприйнятливість освіти вкцючає в себе право обирати вид і тип освітнього закладу. Адаптованість освіти означає, зокрема, що система державної освіти повинна брати до уваги інтереси і можмивості дитини [1] .

Реалізація права на освіту дия всіх дітей, вкцючаючи дітей 3 особливими освітніми потребами (ООП), неможиива без розвитку інклюзивного навчання як спеціально організованого освітнього процесу, що забезпечує дитині з ООП можливості навчання у середовищі одномітків в закладі загальної середньої освіти за стандартними програмами 3 урахуванням iii особливих освітніх потреб. Головне в інклюзивній освіті дитини $з$ ООП - формування освітнього i соціального досвіду разом з ровесниками.

Психолого-педагогічний супровід дітей з ООП в умовах інклюзивного навчання в системі освіти визначається як пріоритетний напрям в діяльності освітніх закладів. Крім того варто зауважити, що психомого-педагогічний супровід на різних вікових етапах має свою специфіку, обумовмену психофізіологічними та соціальними особливостями дитини. А відтак, потребує особмивої уваги організація психомогопедагогічного супроводу підиітків, які мають особливі освітні потреби.

Аналіз останніх досліджень. Аналіз наукової мітератури дозволяє стверджувати, що проблеми здобуття освіти дітьми 3 особливими освітніми потребами перебуває в центрі уваги багатьох вітчизняних та зарубіжних вчених: Е. Андреєвої, В. Андрущенка, А. Гамаюнової, Т. Іияяшенко, І. Смолярчук, М. Сабат, М. Ярмаченкота інших.
Вагомий внесок у формування нової системи освіти зробими $\Lambda$. Коваль, М. Синьов, П. Таланчук та інші.

Різні аспекти теорії і практики впровадження інклюзивної освіти присвячені дослідження таких науковців як В. Бочковський, В. Бондар, А. Колупаєва, В. Аяхова, Г. Хворова та інші.

Концептуальні підходи до соціальнопедагогічного інтегрування дітей та момоді 3 функціонамьними обмеженнями аналізувались І. Івановою, I. Звєрєвою, А. Капською, Г Аактіоновою, Р. Овчаровою, С. Пальчевським.

Наукові роботи Е. Мастюкової, I. Помітової, А. Турубарової присвячені дослідженням соціально-психологічних особливостей підмітків 3 особливими освітніми потребами та проблемам у процесі їхньої соціалізації.

Визначення сутності, мети, завдань, змісту, організації психологопедагогічного супроводу підиітків з особмивими освітніми потребами в умовах інклюзивної освіти висвітлені в наукових роботах 3. Бритаєвої, А. Гамаюнової, I. Овчаренко, М. Аукьяненко, Р. Попемюшко.

мета статті. Розглянути теоретичні засади здійснення психологопедагогічного супроводу підиітків з особмивими освітніми потребами в умовах інкАюзивної освіти.

Виклад основного матеріалу. Інклюзивна освіта - це та складова гуманітарної політики кожної сучасної країни, яка свідчить наскільки їі суспіль-

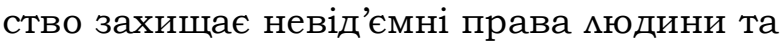
яка сьогодні поступово входить у освітній процес України.

Інкцюзивна освіта - це, передовсім, формування суспільної уваги та поваги до розмаїття та унікальності кожного учня, що, у свою чергу, забезпечує міпшу якість освіти дия всіх дітей.

У дійсно інклюзивному середовищі кожна дитина, у тому числі діти з особмивими освітніми потребами, почуває себе безпечно та має відчуття приналежності до колективу.

Згідно з ЮНЕСКО інклюзивне навчання - це процес звернення і відповіді на різноманітні потреби учнів через забезпечення їхної участі в навчанні, культурних заходах і житті громади та зменшення викцючення в освіті та навчальному процесі. Метою інклюзивного навчання $\epsilon$ покращання навчального середовища, в якому вчитель і учні 
відкриті до різноманіття, де гарантується забезпечення потреб учнів і повага до іх здібностей та можливостей бути успішним

Тобто це такий спосіб отримання освіти, коли учні з особливими освітніми потребами навчаються в загальному освітньому середовищі за місцем свого проживання, - і це є альтернативою інтернатній системі, за якою вони утримуються та навчаються окремо від інших дітей, або домашньому та індивідуальному навчанню [2].

Закон України "Про освіту" визначає інклюзивне навчання як систему освітніх послуг, що забезпечує реалізацію права на освіту осіб з особливими освітніми потребами, а також ї соціалізацію та інтеграцію в суспікьство [6]. У зазначеному Законі України нагомошується на необхідності наданні дітям з особливими освітніми потребами системи освітніх послуг, гарантованих державою, що базуються на принципах недискримінації, врахування багатоманітності цюдини, ефективного залучення та включення до освітнього процесу всіх його учасників.

Метою інклюзивного навчання $€$ реалізація права дітей 3 особливими освітніми потребами на освіту за місцем проживання, їх соціалізацію та інтеграцію у суспільство, залучення сім'і до участі навчально-виховному процесі.

Одним з основних завдань інклюзивного навчання $є$ забезпечення диференційованого психолого-педагогічного супроводу дітей з ООП.

Досвід інтеграції дітей з ООП у загальноосвітньому просторі побудований на основі командної роботи вчителів, медичних працівників, дефектологів, психологів, соціальних педагогів, а також батьків, які повинні рівноправними i компетентними учасниками навчання, розвитку та соціальної адаптації дитини. Питання супроводу дітей з ООП стоїть на перетині функцій багатьох спеціалістів, кожен 3 яких діє в межах своєї компетентності.

Відповідно до статті 1 Закону України «Про реабілітацію осіб 3 інвалідністю" "психолого-педагогічний супровід - системна діяльність.., спрямована на створення комплексної системи клініко-психологічних, психологопедагогічних і психотерапевтичних умов, що сприяють засвоєнню знань, умінь, навичок, успішній адаптації, реабілітації, особистісному становменню особи" [8].
Психолого-педагогічний супровід це комплексна система заходів 3 організації освітнього процесу та розвитку дитини, передбачена індивідуальною програмою розвитку, що включає в себе надання психолого-педагогічних та корекційно-розвиткових послуг.

Психолого-педагогічні послуги - це комплексна система заходів з організації освітнього процесу та розвитку особи 3 особливими освітніми потребами, що передбачені індивідуальною програмою розвитку та надаються педагогічними працівниками закладів освіти.

Корекційно-розвиткові послуги - це комплексна система заходів супроводження особи з особливими освітніми потребами у процесі навчання, що спрямовані на корекцію порушень шляхом розвитку особистості, їі пізнавальної діяльності, емоційно-вольової сфери та мовмення [7].

Психолого-педагогічний супровід дітей з особливими освітніми потребами - це завжди пролонгований, динамічний процес, цілісна командна діяльність. Психолого-педагогічний супровід дітей 3 ООП в умовах інклюзії забезпечується командою фахівців, кожен чиен якої не цише має виконувати свої функції, але й вміти узгоджувати та координувати свої дії з іншими спеціалістами. Досягти цього можна мише в рамках командного підходу, коли можливості всіх фахівців органічно поєднуються та спрямовуються на досягнення мети повноцінного навчання, виховання та реабілітації школяра. Згідно Положення про команду психолого-педагогічного супроводу дитини з особливими освітніми потребами в закладі загальної середньої та дошкільної освіти до складу команди супроводу у закладі загальної середньої освіти входять постійні учасники: директор або заступник директора 3 навчальновиховної роботи, вчитель початкових класів (класний керівник), вчителі, асистент вчителя, практичний психолог, соціальний педагог, вчитель-дефектолог, вчитель-реабілітолог, батьки або законні представники, а також залучені фахівці: медичний працівник закладу освіти, асистент дитини, спеціалісти системи соціального захисту, служби у справах дітей тощо [7].

Метою психолого-педагогічного супроводу дітей з ООП в закладах загальної середньої освіти є вивчення особистісного потенціалу, а саме: співвідношення 
рівня розумового розвитку дитини i вікової норми, розвитку когнітивної сфери, сформованості мотивації до навчання; особливості емоційно-вольової сфери; індивідуально-характерологічні особливості, іх творчій та інтелектуальний розвиток через залучення всіх учасників навчально-виховного процесу (батьків, педагогів, дітей) до реалізації запланованих дій щодо особливостей розвитку; соціалізація та адаптація; професійно орієнтація дітей 3 особливими потребами [3].

Слід зауважити, що й дитина, яка має особливості розвиту, і дитина здорова розвиваються за однаковими законам психічного розвитку. На їнній розвиток впливають і біологічні, і соціальні фактори. Говорячи про біологічні фактори, ми акцентуємо увагу саме на об'єктивних особливостях і характерних вцастивостях підліткового віку, що є притаманними i для дітей 3 особливими освітніми потребами.

Підлітковий вік охоплює період від 11-12 до 14-15 років, що відповідає середньому шкільному вікові, тобто 5-9 класам школи. У цей період в особистості дитини відбуваються складні і суперечмиві зміни, на підставі чого його ще називають важким, критичним, перехідним. Така оцінка зумовлена багатьма якісними трансформаціями, які нерідко пов'язані з докорінними змінами попередніх соціальних ролей, особливостей активності, інтересів і стосунків дитини. Відбуваються вони за порівняно короткий час, здебільшого бувають несподіваними i надають процесові розвитку стрибкоподібного, бурхливого характеру. Майже завжди ці зміни супроводжуються появою у підмітка суб'єктивних труднощів.

Ускладнюється і його виховання, оскільки підліток не підкорюється ефективним, щодо молодшого школяра, впливам дорослих, у різних формах проявляє непослух, опір і протест (упертість, грубість, негативізм, замкнутість) [9].

У підлітковому, як і в молодшому шкільному віці, основним соціальним середовищем дитини залишається шкома. Зовнішні умови розвитку тісно пов'язані із внутрішніми. На основі вищого, ніж у молодших школярів, рівня психічного та особистісного розвитку відбуваються докорінні зміни у змісті і співвідношенні основних мотиваційних тенденцій особистості підлітка.
На цьому етапі у дитини виникає специфічний комплекс потреб, що виражається в прагненні знайти своє місце у групі ровесників, вийти за межі школи.

Своєрідність соціальної ситуації розвитку підлітка полягає у включенні його до нової системи стосунків, спілкування 3 дорослими та ровесниками, в опануванні нових соціальних функцій. У школі це виявляється передусім у необхідності налагодження у зв'язку з предметним навчанням стосунків не $з$ одним, а з багатьма вчителями, врахування особистісних якостей кожного 3 них i ix нерідко суперечливих вимог. Усе це зумовлює нову позицію учнів щодо вчителів, своєрідно емансипує іх від безпосереднього впливу дорослих, робить їх самостійнішими. Найголовніша зміна в соціальній ситуації розвитку підлітка породжена ром^ю в його житті групи ровесників.

Основним чинником розвитку підлітка $є$ його власна соціальна активність, спрямована на засвоєння важливих для нього зразків поведінки і цінностей, на побудову стосунків з дорослими, ровесниками. Підлітки включаються у різні види суспільно корисної діяльності, що розширює сферу їхнього спілкування, можливості засвоєння соціальних цінностей, сприяє формуванню моральних якостей.

Отже, дия соціальної ситуації розвитку підмітка характерні перехід до середньої школи, зміна стосунків з учителями, однолітками, батьками, розширення сфери соціальної активності.

Становцення психологічного механізму, що формує навички та вміння враховувати інтереси іншої $ю$ юини у процесі спілкування та взаємодії, відбувається саме у підиітковому віці. 3 одного боку, прагнення до незалежності, дорослі домагання, вимоги рівних з ними прав, розширення меж самостійності, а 3 іншого - недостатня психологічна та соціальна зрілість потребують допомоги і підтримки з боку дорослих, запобіжних дій щодо виникнення та розвитку у підлітків ризикованої поведінки.

Необхідність різних форм психологопедагогічного супроводу підмітків з особАивими освітніми потребами (ООП) в умовах інкАюзивної освіти обумовлюється особливостями їхньої пізнавальної діяльності та емоційно-вольовою сферою, відхиленнями у поведінці, а також об'єктивними віковими соціально- 
психологічними вцастивостями. Діти 3 ООП демонструють низьку пізнавальну активність, недостатню сформованість мотиваційно-потребнісної та емоційної сфер, затримку або порушення мовного розвитку, не сформованість комунікативних навичок та інші відхимення у розвитку. Зазначені психологічні особливості можуть зустрічатися у дітей у різних комбінаціях та мати різний ступінь прояву, що передбачає індивідуальний характер їхнього психолого-педагогічного супроводу, в умовах інклюзивної освіти [5].

На наш погляд найбільш важливими напрямами роботи у процесі здійснення психоцого-педагогічного підцітків з ООП є наступні.

Профілактичний напрям. Профікактика - один $з$ основних напрямів діяльності у процесі реалізації психологопедагогічного супроводу в закладі загальної середньої освіти, що дозволяє попередити вторинні відхимення у розвитку і труднощі навчання на початковому етапі шляхом створення дия учня доступних умов дмя здійснення змістовної діяльності, що сприяє його психічному розвитку.

Дия підліткового віку актуальними $є$ проблеми виникнення шкідливих звичок та схильностей (паління, алкоголізм, наркоманія, асоціальна поведінка тощо). Основа профікактики цих явищ - формування установок на здоровий спосіб життя, навичок протистояння негативному впливу, залучення до практичної діяльності здоров'язбережувального характеру.

Діагностичний напрям ставить за мету прогнозування можливих труднощів навчання, визначення їх причин i механізмів вирішення існуючих проблем. При цьому використовується широкий спектр методів: тестування, спостереження, бесіда, аналіз продуктів різних видів діяльності підлітка, документації, наявної в освітньому закладі, дослідження найближчого оточення школяра. У процесі оцінки результатів діагностики необхідно орієнтуватись на потенційні можливості дитини, тобто оцінювати не тільки рівень актуального розвитку, але й зону найближчого розвитку.

Діагностичний консиліум наприкінці навчального року визначає рівень розвитку дитини, пізнавальної діяльності, результатів навчання. Крім того, кожен зі спеціалістів здійснює регулярний моніторинг реалізації корекційноосвітнього процесу (групового та індивідуального). На основі результатів діагностики складається індивідуальна кореційно-освітня програма дмя кожного підиітка.

Консультативний напрям. Психологопедагогічне консультування - важливий різновид практичної роботи, орієнтований на підлітків та старших школярів. Консультування може мати різний зміст, стосуватися як проблем професійного або особистісного самовизначення шкомяра, так і різних аспектів його взаємин

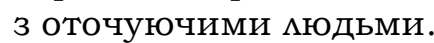

В межах консультативної роботи можуть бути вирішені наступні завдання: надання допомоги підміткам, які відчувають труднощі у навчанні, спілкуванні або мають проблеми у психічному самопочутті; розвиток у підлітків навичок самопізнання, самореалізації і самоаналізу, використання своїх соціальнопсихологічних особливостей дмя успішного навчання та розвитку; надання психомогічної допомоги і підтримки школярам у стані стресу, конфмікту, сильного емоційного переживання.

З урахуванням цього консультування може бути індивідуальним або груповим.

Індивідуальне консультування - надання допомоги та створення умов дмя розвитку особистості, здібностей обирати та діяти на власний розсуд, для формування нових форм поведінки.

Групове консультування - інформування всіх учасників освітнього процесу щодо питань, пов'язаних з особливостями освітнього процесу дмля даної категорії дітей з метою створення адаптивного середовища, що надає можливість забезпечити повноцінну інтеграцію і особистісну самореалізацію в освітньому закладі.

Корекційний та розвиваючий напрям. Ці два напрями доцільно розглядати разом, оскільки обидва $€$ частиною освітнього процесу. Навчання, виховання і розвиток дітей з ООП має корекційну спрямованість, при чому корекційна робота пов'язана із виправленням відхи$\Lambda$ ень, а розвиваюча - з розкриттям потенційних можливостей дитини, удосконаменням фізичних і психічних функцій. Напрями корекційно-розвиваючої роботи різноманітні: сенсомоторний розвиток; формування просторово-часових уявмень, формування відповідних віку загамьно інтелектуальних умінь: розвиток наочних i вербальних фрорм мислення, 
нормалізація провідного виду діяльності; розвиток зв'язного мовлення; готовність до сприйняття навчального матеріалу, формування необхідних дия засвоєння програмного матеріалу вмінь та навичок.

За результатами діагностики, рекомендацій спеціалістів, котрі здійснюють психолого-педагогічний супровід підмітка с ООП складається комплексна корекційно-освітня програма, що визначає всі види корекційної допомоги, пї шляхи та часові терміни реалізації, розклад занять. Оцінка результативності здійснюється на основі систематичного психологопедагогічного спостереження за учнем у ході навчальної та інших видів діяльності.

Корекційно-розвиваюча робота в умовах інклюзивної освіти передбачає, разом 3 корекцією психічних функцій $\mathrm{i}$ пізнавального розвитку, інтенсивне накопичення соціального досвіду, розвиток комунікативних умінь та навичок як вербального, так не вербального характеру, необхідних підліткам з ООП для вибудовування міжособистісного спілкування у середовищі однолітків, які мають нормацьний розвиток, та дорослих. Формування комунікативних умінь здійснюється на предметних уроках, корекційних заняттях, позакласної роботи (класні години, гурткова робота, дозвільнорозважальна та добровільна соціальнокорисна діяльність). Однак особливе значення має спеціально організована прозаурочна діяльність спрямована на розвиток комунікативних навичок (факультативи, метою яки $є$ розвиток комунікативних навичок, клуби спілкування тощо). Використання у ній таких інтерактивних форм навчання як ігри, тренінги, моделювання ситуацій, презентація продуктів творчої діяльності, сприятиме задоволенню потребам дітей, що мають ООП, у неформальному спілкуванні, в оволодінні інформації про себе, риси свого характеру, здібності, формуватиме

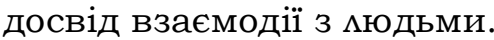

Просвітницький напрям. Психологопедагогічне просвітництво у системі інклюзивної освіти спрямовано на формування адекватного ставлення суспільства до гуманного відношення до них, визнання ix прав і свобод.

Інформування батьків щодо специфіки організації інклюзивної совіти, консультації з питань батьківської участі і допомоги у процесі спільного навчання дітей різних категорій, надання рекомендацій щодо налагодження адекватних i гармонійних взаємин у родині - найваж- мивіша складова ефективної взаємодій сім ї та школи.

Психолого-педагогічне просвітництво ставить за мету формування потреби у психологічних знаннях в учнів, педагогів, батьків, бажання використовувати іх в інтересах як особистісного розвитку вихованців, так і вцасного розвитку, своєчасно попередження можливих порушень у розвитку.

Профорієнтаційний напрям. Концепція системи професійної освіти осіб 3 ООП в Україні на сучасному етапі базується на розумінні професійної освіти як важливішого фактору ї соціальної реабілітації. Процес професійної орієнтації нерозривно пов'язаний 3 психологопедагогічною, соціальною, корекційною, медичною підтримкою тих, хто навчається. Вона передбачає вивчення особмивостей розвитку і освітніх потреб учнів, динамічне спостереження за іх просуванням в освітньому процесі, формування мотивованих професійних намірів, встановлення відповідності індивідуальних психологічних i особистісних особливостей вимогам тієї чи іншої професіі. Профорієнтаційна робота з підлітками з ООП в умовах інклюзії, на жаль, поки ще не $€$ організаційно цілісною, ефективно діючою системою. Вона знаходиться в стадії пошуку нових модемей, технологій, ресурсного забезпечення.

Розширення кола агентів соціалізації, осіб, які досягли значних життєвих результатів, не дивлячись на обмежені можАивості здоров'я (параолімпійські чемпіони, діячі культури, мистецтва, науки), об'єднання дітей-інвалідів (сайти, інтернспільноти, мережеві асоціації тощо) створюють додаткові умова для демонстрації можливостей отримання професії, запитів ринку праці тощо.

Висновки. Отже, ефективність та дієвість психолого-педагогічного супроводу підлітків з ООП у закладах загальної середньої освіти визначатиметься наявністю цілісної системи діяльності всіх учасників освітньо-корекційного середовища, побудованого на врахуванні індивідуально-характерологічних, вікових, розумових, емоційно-вольових особливостей дітей зазначеної вікової категорії.

\section{Список бібліографічних посимань}

1. Алехина С.В., Семаго М.М. Создание и апробация модели психолого-педагогического сопровождения инклюзивной практики. Москва: МГППУ, 2012. 156 c.

2. Комупаєва А., Савчук $\Lambda$. Діти з особливими освітніми потребами та організація їх навчання. Київ: Науковий світ, 2010. 196 с.

3. Овчаренко I.В. Психологічний супровід дитини 3 особливими освітніми потребами в інклюзивному 
кмасі. Таврійський вісник освіти. 2017. №1(57). C. $249-254$

4. Психологічний супровід інклюзивної освіти: методичні рекомендації / авт. кол. за заг. ред. А.Г.Обухівська. Київ: УНМЦ практичної психомогії і соціальної роботи, 2017. 92 с.

5. Попелюшко Р.П. Психолого-педагогічний супровід дітей 3 особливими потребами в інклюзивному навчанні. Збірник наукових праиь Хмельнииького інституту соиіальних технологій Університету "Україна". 2014. №1(9). С.109-113.

6. Про освіту: Закон України від 05.09.2017 p. №2145-VII. Відомості Верховної Ради. 2017. №38-39. Ст. 380.

7. Про затвердження примірного положення про команду псиного-педагогічного супроводу дітей 3 особливими освітніми потребами в закладах загацьної та дошкільної освіти: затв. наказом МОН від 08.07.2018 p. № 609. URL: https://zakon.rada. gov.ua/rada/show/v0609729-18.

8. Про реабілітацію осіб з інвалідністю: Закон Украіни від 19.12.2017 p. №2249-VIII/ URL: https://zakon.rada.gov.ua/laws/show/2961-15.

9. Турубарова А.В. Соціально-психологічні проблеми соціалізації підлітків із особливими освітніми потребами. Науковий вісник херсонського державного університету. 2014. Випуск2. Том 2. С.77-81.

\section{References}

1. Alekhina S.V., Semago M.M. (2012). Creation and approbation of the model of psychological and pedagogical support of inclusive practice. Moscow: MGPPU. 156 p.
2. Kolupaeva A., Savchuk L. (2010). Children with special educational needs and organization of their education. Kyiv: Scientific World. 196 p.

3. Ovcharenko I.V. (2017). Psychological support for a child with special educational needs in the inclusive class. Tavria Education Bulletin. 1(57). 249-254.

4. Psychological support of inclusive education: methodical recommendations (2017). In A.H. Obuhivska (Ed.) and etc. Kyiv: UNMTS of practical psychology and social work. $92 \mathrm{p}$.

5. Popelyushko R.P. (2014). Psychological and pedagogical support for children with special needs in inclusive education. Collection of research papers of the Khmelnytsky Institute of Social Technologies of "Ukraine" University. 1(9). 109-113.

6. On education (2017). Law of Ukraine dated $09 / 59 / 2017$, number 2145-VII. Information from the Verkhovna Rada. No. 38-39. Art.380.

7. On approval of the exemplary thesis of the team of psycho-pedagogical support for children with special educational needs in institutions of general and pre-school education: Sanctioned by Order of the Ministry of Education and Science on 08.07.2018 №609. URL: https://zakon.rada.gov.ua/rada /show/v0609729-18.

8. On Rehabilitation of Persons with Disabilities: Law of Ukraine dated January 19, 2017 No. 2449-VIII. URL: https://zakon.rada.gov.ua/laws/show/296115.

9. Turubarova A.V. (2014). Socio-psychological problems of socialization of teenagers with special educational needs. Bulletin of Kherson State University. Issue 2. Vol. 2. 77-81.

\title{
MYKHAILENKO Oksana Volodymyrivna,
}

Associate Professor of Social Work Department,

\author{
National T.H. Shevchenko University "Chernihiv Colehium"
}

\section{MAIN DIRECTIONS OF PSYCHOLOGICAL AND PEDAGOGICAL ACCOMPANIMENT OF TEENAGERS WITH SPECIFIC EDUCATIONAL INTERESTS IN INCLUSIVE EDUCATION}

Abstract. Implementation of education rights for all children, including children with specific educational interests (SEI), isn't possible without development of inclusive education as a specially organized educational process, providing a child with SEI capabilities to learn in a secondary school according to established educational programs, taking into account their specific educational interests.

Psychological and pedagogical support for children with SEI in inclusive education in the education system is defined as a priority area of educational institutions.

The target of the article is to consider the theoretical foundations of psychological and pedagogical support of units of the SEI in inclusive education.

Main results of the study. According to UNESCO, inclusive education is a process of addressing and responding to the diverse interests of students through ensuring their participation in educational, cultural activities and communities and reducing of elimination from education and learning process.

The purpose of inclusive education is the realization of the rights of children with SEI to education of local residence, their coalitions and integration into society, involvement of the family in participation in the educational process.

One of the main tasks of inclusive education is to provide differentiated psychological and pedagogical support for children with SEI.

Psycho-pedagogical support is a complex system of measurements for organization of educational process and child's development, provided by an individual program of development, which includes psychological and pedagogical and correction-developed services.

The need for other forms of psychological and pedagogical support for teenagers with SEI in inclusive education is supported by the features of their cognitive activity and the emotional and volitional sphere, behavior deviation and age specific social and psychological features.

In our opinion, the most important areas of work in the implementation of psychological and pedagogical support of teenagers are: preventive, diagnostic, advisory, corrective and developing, educational and vocational guidance.

Conclusions. So, the evaluation of the effectiveness and efficiency of psychological and pedagogical support of teenagers with SEI in institutions of general secondary education is determined by the activities of the target system of all participants in educational and correctional environment, built on individual and characterological, age, and mental features of mentioned categories.

Keywords: children and adolescents with special educational needs; psychological and pedagogical support for children with special educational needs; inclusive education; inclusive education; team of psychological and pedagogical support.

Одержано редакиією 18.012019 Прийнято до публікайї 23.012019 